\title{
The Ride-Hailing Mobile Application for Personalized Travelling
}

\author{
Ziad Hunaiti ${ }^{1}$, Mohammed Al Masarweh ${ }^{2}$, Zayed Huneiti ${ }^{3}$, Ahmad Alshebailat $^{4}$ \& Marzia Hoque Tania ${ }^{4}$ \\ ${ }^{1}$ Knowledge Well Limited, United Kingdom \\ ${ }^{2}$ Managment Information System, Collage of Business in Rabigh, King Abdulaziz University, Saudi Arabia \\ ${ }^{3}$ Department of Electrical Engineering, college of Engineering Technology, Al-Balqa Applied University, Jordan \\ ${ }^{4}$ Anglia Ruskin University, United Kingdom \\ Correspondence: Ziad Hunaiti, Knowledge Well Limited, United Kingdom. E-mail: Ziad@Knowledgewell.co.uk
}

Received: March 16, 2018 Accepted: September 20, 2018 Online Published: October 29, 2018

doi:10.5539/mas.v12n11p244 URL: https://doi.org/10.5539/mas.v12n11p244

\begin{abstract}
Theadvancement of smartphones, global positioning system, and information technologies have a great influence on our travelling preferences and behaviour, dynamically shaping the transportation industry. In addition to providing convenience to the riders, it also has created some debate among the stakeholders, including the policy makers. This paper presents a quantitative study of Taxi service experience in Jordan. The aim of the study is to evaluate Jordanians' experiences with yellow taxi services, assess their opinion toward advantages and disadvantages of Uber taxi services in Jordan and obtain opinions on the expected future of Uber taxi services.
\end{abstract}

Keywords: ride sharing, ride-sourcing, ride-splitting, smartphone-enabled applications, third-party taxi services, transportation, quantitative study, GPS, GIS, Information System

\section{Introduction}

Taxis can play an important role to provide a personalised point- to-point transportation service, especially in the urban areas. Effective taxi services can significantly reduce the number of private cars on the road (Jha et al., 2018). The technological advancements in the industry of transportation and mobile devices have paved the way for smartphone enabled ride-hailing services (Maqableh \& Karajeh, 2014). Initially such services used to be referred as ride-sharing or peer-to-peer mobility services. California Public Utilities Commission (2013) stated such services to be referred as transportation network companies. However, they are still colloquially known as ride sharing, ridesourcing, ride-splitting or ride-haling services. In 2009, Uber emerged as of the first service to provide such facilities ("Uber," 2018).

\subsection{Uber as a Ride-Hailing Application}

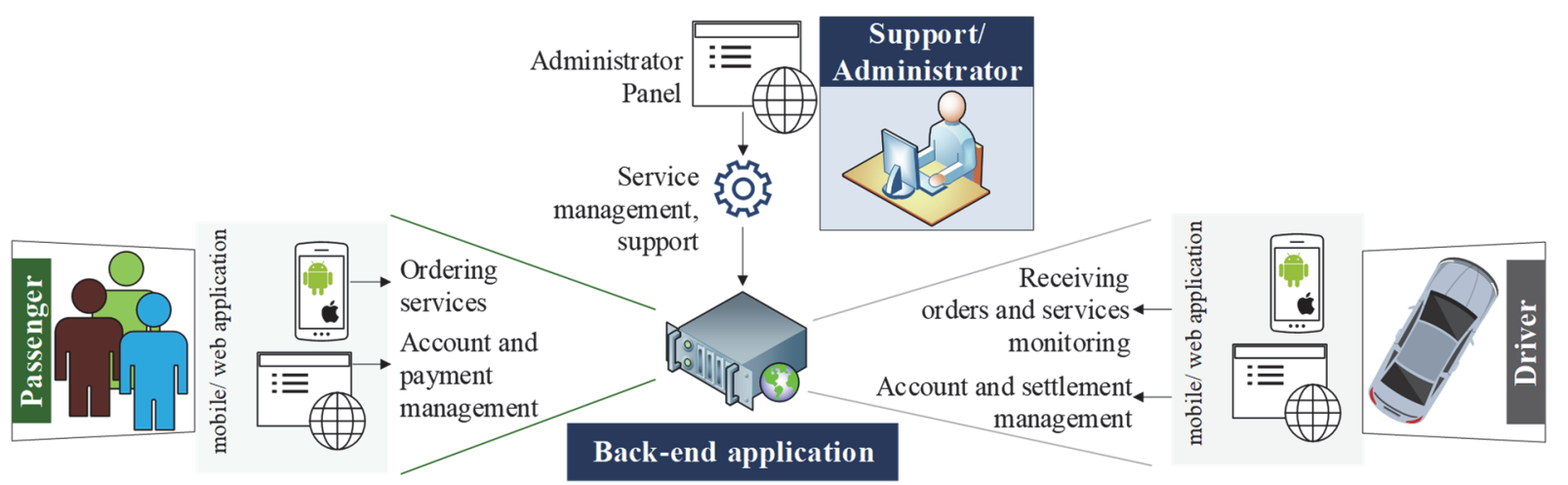

Figure 1. Uber mechanism

The Uber technology platform aids the driver-partners and the riders to be connected through a smartphone application. The mechanism is illustrated in Figure 1 (Wegner, 2017). The rider can use the application using passenger's account to request a ride in the Uber-cities. In response, when a neighboringdriver-partner accepts the 
request, the application lets the rider know a projection of arrival time to the passenger's location. The application also updates the rider when the driver-partner is almost near to the location. Unlike the traditional taxi, as the Uber cars do not possess any distinctive visual appearance, the application also provides few valuable information to the rider such as the type of the vehicle, license plate number, approved information regarding driver's identity to facilitate the rider to identify the driver-partner at pickup location.

The rider has the freedom to express the preference about route course to the destination. The destination can be specified through the application prior or during the journey. The journey is terminated at the destination point, followed by automatic calculation of the fare. The cost is payable in the rider-defined method, which varies in different Uber-cities. However, the payment method needs to be specified before sending a ride-request. The Uber-technology initiated a bidirectional user evaluation system. Therefore, the rider as well as the driver-partner can appraise the experience at the termination of the journey inspiring a social movement.

Globally, there are 75 million people who uses the Uber ride-hailing mobile application (Bhuiyan, 2018). There are 3 million Uber drivers. Uber is being used in 65 countries, over 600 cities. Uber reported to provide 10 million rides per day ("Uber," 2018). In 2016, Uber's share of the ride-hailing market in US was near $85 \%$ (Hartmans, 2016).

In spite of being a promising start-up, Uber is facing many challenges. The foremost challenge facing Uber is common to all forms of mechanisation since the 19th century Luddites: the (justified) fear that technological improvements take away people's livelihoods. Taxi drivers are the recognisable victims in the case of Uber. Traditional or yellow taxi drivers generally undergo additional training in driving and are subject to regulations and criminal background checks etc.; conversely, Uber has traditionally had an open-door policy in terms of who it allows to drive its passengers. This is inherently disadvantageous to traditional taxi drivers and firms, and indeed detrimental to passenger safety, regardless of employment issues (Zhao, Dimovitz, Staveland, \&Medsker, 2016). However, the most vocal opposition to Uber has been on the grounds of employment (i.e. taxi drivers losing their jobs), which was the main rationale for some countries and municipalities banning the service (Gerdes \& Thornton, 2015). The global taxi business developed over centuries (e.g. from horse-drawn hackney cabs in Victorian London) and is a major economic sector in its own right, generating employment for millions of people worldwide and producing large revenues, all of which is threatened by Uber.

Furthermore, Uber drivers are also increasingly concerned about their employment rights, as they do not in fact have the protections enjoyed by conventional employees; as a result of legal agitation, Uber was forced to pay substantial sums to about 400,000 cab drivers worldwide (Gerdes \& Thornton, 2015). Uber seeks to view Uber drivers and subcontracting parties in a transaction between itself and passengers, but regulatory bodies and drivers themselves are increasingly wary of allowing Uber to escape the conventional expectations of taxi companies toward their employees by exploiting its aberrant technological advantage in following what is otherwise a traditional taxi business model.

Indeed, Uber's aggressive and predatory policies, such as its callous disregard for the livelihoods of yellow cab and Uber taxi drivers, indicate an ethical void at the heart of globalised business culture stemming from an outdated utilitarian vision of capitalist exploitation for short-term economic gain that is increasingly unfit for the purposes of the 21 st century globalised world (Valladão, 2016).

\subsection{Jordan as a Case Study}

The Hashemite Kingdom of Jordan, located in southwest Asia, is bounded on the north by Syria, the east by Iraq, the southeast by Saudi Arabia and from the west by Palestine (Ministry of Tourism and Antiquities, 2017). The population in Jordan in 2016 was estimated at 9.7 million, having increased exponentially from under 600,000 in 1952. Jordan's unemployment rate for 2016 rose by $1.6 \%$ to reach $15.3 \%$ (GOS, 2017). The results of the Employment and Unemployment Survey for 2016 showed that illiterate young people constituted a small percentage of $0.8 \%$; the results also indicate that $96 \%$ of young people are enrolled in study. The average wage in 2014 for both males and females was approximately $\$ 8,000$ p.a., about 14 percent of which is spent on transportation (Iman, 2014).

Jordan has a wide network of roads linking the northern, southern, eastern and western sides. Amman, the capital city of Jordan, is one of the fastest-growing and most densely populated cities in the Middle East, containing over a third of the Jordanian population. There are few buses operating in Amman, but they cover the main routes and fares are cheap. Buses are the most prevalent form of transport between cities, but taxis are the most common within cities. The normal taxi is yellow or grey, called a momayaz, which is considered a "special taxi" with additional services that the passenger can order, which is very popular in the streets of Amman (Ministry of Tourism and Antiquities, 2017). However, in recent years the quality of taxi services and customer satisfaction has 
steadily declined (Iman, 2014).

This has made Amman ripe for penetration by Uber and similar services seeking to meet public demand for efficient taxi services, and the population rapidly embraced Uber, invoking the anger and consternation of the yellow cab drivers disenfranchised from their traditional monopoly. However, the lack of existing research about this subject inspired the undertaking of this study to fill the gap in the literature and provide useful recommendations for main stakeholders.

\section{Literature Review}

There are number of patents for the ride hailing mechanism (US9157748B2, 2013, US9488494B2, 2015, US9934691B2, 2016). In the recent literature, considerable amount of focus has been provided to the economic perspective of the ride-hailing applications (Chen \& Sheldon, 2016; Kim, Baek, \& Lee, 2018; Lee, Park, \& Lee, 2018; Zha, Yin, \& Du, 2017; Zha, Yin, \& Yang, 2016). Few studies have been also conducted on the social aspects of this shared economy (Peticca-Harris, Degama, \&Ravishankar, 2018; Smith \& McCormick, 2019).

Having a great influence on the personalised travel mode in US market, studies have been conducted on cities such as New York (Salnikov, Lambiotte, Noulas, \&Mascolo, 2015), Washington DC, (Yang et al., 2018), Atlanta (Wang $\& \mathrm{Mu}, 2018$ ) and San Francisco (Glöss, McGregor, \& Brown, 2016).

In literature, the implications of Uber in the urban transportation system has been studied for metropolitan cities e.g. London (Glöss et al., 2016), Toronto (Haider, Donaldson, \&Nourinejad, 2015), Delhi (Kashyap, 2018). Studies have been also heighted DiDi- another strong company in the ride-hailing industry (Jacquet, 2018; Jiang, Chen, Mislove, \& Wilson, 2018; Zhang, Guo, Li, \& Liu, 2016).

To the best of authors' knowledge, there is no existing study that can illustrate how these ride-hailing applications are affecting the personalised travelling experience in Jordan. Imam (2014) studied the methodological issues pertaining to the investigation of satisfaction with public transportation in Amman. The key finding from the study revealed that, in general, passengers are not satisfied from public transportation in Amman, and the author recommended that extensive work is needed to overhaul and improve the system to solve endemic and serious problems like congestion, accidents, noise, air pollution and fuel consumption. Therefore, there is a need of elaborate study on travel experience and behaviour which can help the policy makers to create a harmony in the disrupted traditional transportation industry while providing a better service to its citizens.

\section{Research Design and Methodology}

Based on the preliminary finding from our qualitative study using focus group, we designed the questionnaire using a five-point Likert scale to efficiently quantify the opinions of passengers about using taxis in Jordan. The simplicity and low cost of this method are additional advantages to its ability to quickly glean quality data from large groups of people, and the data can be easily analysed used statistical packages such as SPSS. A pilot study was conducted to test that participants could understand all items and to invite any feedback prior to actually conducting the study fieldwork (Landau \&Everitt, 2004).

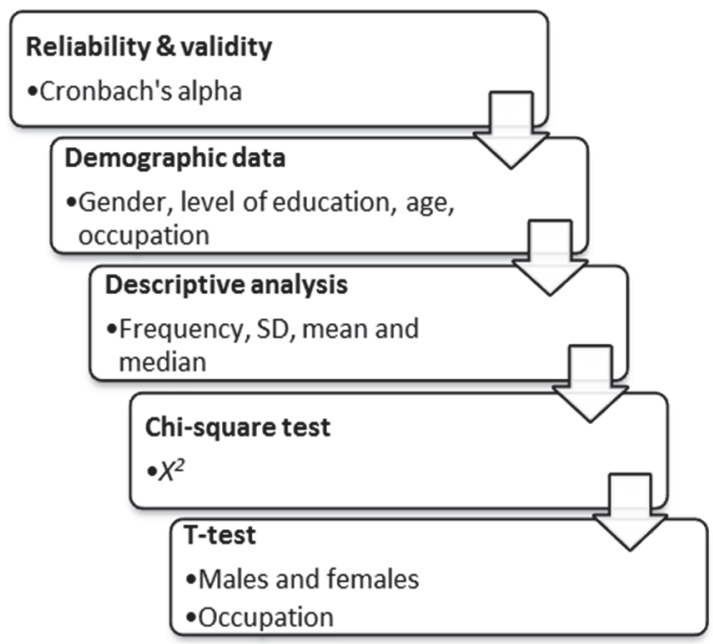

Figure 2. Questionnaire data analysis process

The use of a five-point Likert scale for the questionnaire meant that the data was easy to process digitally using 
advanced analysis options in SPSS or standard spreadsheets in MS Excel. The collected data reliability can be tested, and descriptive statistic data can be presented according to each question in the questionnaire; graphs can be generated and advanced statistical test can be performed to compare between deferent group and questions (Creswell, 2003). Figure 1 shows the process of analysing data from the questionnaire.

\subsection{Reliability and Validity Testing}

The reliability was calculated using Cronbach's alpha equation:

$$
\text { Reliability coefficient }=\frac{n}{N-1} * \frac{1-\text { Totalvariationsquestions }}{\text { variationcollegegrades }}
$$

\subsection{Demographic Data}

Analysis of gender, level of education, age group and occupation was important to present general information related to participants as well as to provide good grounds to make categories to conduct comparison and test any differences between different groups (e.g. male and female, level of education, age group and occupation).

\subsection{Descriptive Analysis}

This part of test was conducted to obtain a general view on the collected votes on each item within each list and translate that into strongly agree, agree, neutral, disagree and strongly disagree.

\subsection{Chi-Square Test}

Chi-square Test is useful to test whether the distribution of data between the voters is significantly different.

\subsection{T-Test}

T-test was conducted twice in order to see if the responses between different groups were of statistical significance. It was performed between males and females, T-test between usage categorisation (frequent or occasional) and ANOVA test between four groups of users ( 1 to 10,11 to 20,21 to 30 and $>30$, known as sections 1-4 respectively).

\subsection{ANOVA Test}

One-way analysis of variance (ANOVA) was conducted to see if there were significant differences between four groups of users (sections 1-4).

\section{Results and Discussion}

\subsection{Data Collection and Pilot Study}

Before the formal data collection, the survey was filled by five volunteers in order to gather feedback on structure, clarity of statements, grammatical mistakes or any deficiencies that might have negatively effects on data analysis or findings. Moreover, the pilot study yielded an indication of how the results might be presented.

The general information about participants including gender, age group, occupation and frequency of taxi use were collected. The questionnaire was electronically distributed to nearly 400 people and 148 completed responses were received, representing a response rate of $37 \%$. The key objective of this study was to gather sufficient responses regarding the identified factors.

\subsection{Data Analysis}

\subsubsection{Cronbach's Alpha}

Cronbach's alpha was used in order to make sure the collected data is reliable and can be depended upon in subsequent analysis to provide suitable grounds for making conclusions. A Cronbach's alpha coefficient from Eq. 1 of (0.90) indicates high reliability and the stability of the scale and the validity of the study. The validity coefficient (the square of the islands) is (0.95), which shows that the scale is authentic and beneficial in relation to the studied phenomena.

\subsubsection{Demographic Data}

The demographic information can be visualised from Figure 2 . The gender distribution is not heavily imbalanced. Figure 2 illustrates the view of the distribution of the sample by male (58.1\%) and female (41.9\%). 


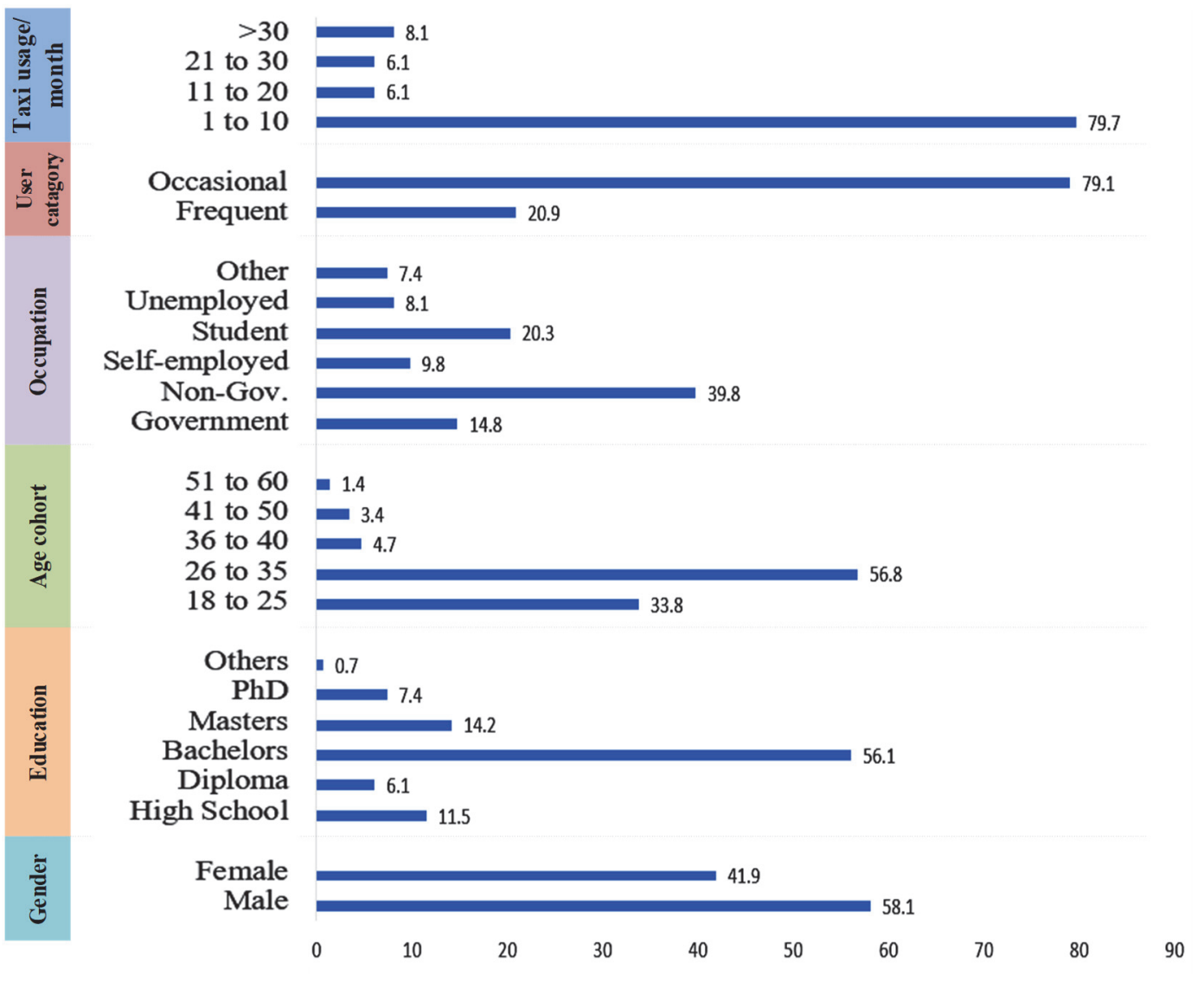

Figure 3. Demographic information

The distribution of the sample by education according was High School (11.5\%), Diploma (6.1\%), BSc (56.1\%), MSc (14.2\%), $\mathrm{PhD}(7.4 \%)$ and other $(0.7 \%)$. Most of our samplesrepresents younger demographic. The distribution of the sample by age cohort: 18 to 25 (33.8\%), 26 to $35(56.8 \%), 36$ to $40(4.7 \%)$ and 41 to $50(3.4 \%)$ and 51 to $60(1.4 \%)$. The occupation of the participants can be categorised as: government $(14.8 \%)$, nongovernment (39.8\%), self-employed (9.8\%), student $(20.3 \%)$, unemployed $(8.1 \%)$ and other $(7.4 \%)$.

Most of our participants were occasional taxi users (79.1\%). Only $20.9 \%$ of the sample are frequent taxi users. The distribution of monthly usage of taxi services of the sample can be viewed from Figure 2 as 1 to $10(79.7 \%), 11$ to $20(6.1 \%), 21$ to $30(6.1 \%)$, student $(20.3 \%)$ and $>30(8.1 \%)$.

\subsection{Experience with Yellow Taxis}

Table 1 illustrates the frequencies for respondents' answers concerning their experience with yellow taxis before Uber.Table 2 illustrates Chi-square test results for respondents' answers about their experiences with yellow taxis before Uber.

Table 1. Experiences with taxis before Uber

\begin{tabular}{|c|c|c|c|c|c|}
\hline Statement & $\begin{array}{l}\text { Strongly } \\
\text { agree }\end{array}$ & Agree & Neutral & Disagree & $\begin{array}{l}\text { Strongly } \\
\text { disagree }\end{array}$ \\
\hline \multirow{2}{*}{$\begin{array}{l}\text { 1. I have to walk some distance to catch a yellow } \\
\text { taxi }\end{array}$} & 56 & 21 & 37 & 24 & 10 \\
\hline & 37.8 & 14.2 & 25.0 & 16.2 & 6.8 \\
\hline 2. Yellow taxi drivers are sometimes picky; I prefer & 70 & 30 & 24 & 14 & 10 \\
\hline $\begin{array}{l}\text { young drivers or individuals without family } \\
\text { luggage }\end{array}$ & 47.3 & 20.3 & 16.2 & 9.5 & 6.8 \\
\hline
\end{tabular}




\begin{tabular}{|c|c|c|c|c|c|}
\hline \multirow{2}{*}{$\begin{array}{l}\text { 3. Yellow taxi drivers sometimes refuse to go to } \\
\text { some destinations or routes }\end{array}$} & 92 & 27 & 12 & 10 & 7 \\
\hline & 62.2 & 18.2 & 8.1 & 6.8 & 4.7 \\
\hline \multirow[t]{2}{*}{ 4. Some yellow taxi drivers are rude } & 57 & 39 & 34 & 11 & 7 \\
\hline & 38.5 & 26.4 & 23.0 & 7.4 & 4.7 \\
\hline \multirow{2}{*}{$\begin{array}{l}\text { 5. Some yellow taxi drivers ask for higher } \\
\text { fare/payment or do not use the meter }\end{array}$} & 52 & 38 & 33 & 18 & 7 \\
\hline & 35.1 & 25.7 & 22.3 & 12.2 & 4.7 \\
\hline \multirow{2}{*}{$\begin{array}{l}\text { 6. Some yellow taxi drivers get other passengers to } \\
\text { share with you to maximise their income }\end{array}$} & 40 & 28 & 38 & 30 & 12 \\
\hline & 27.0 & 18.9 & 25.7 & 20.3 & 8.1 \\
\hline \multirow[t]{2}{*}{ 7. Some yellow taxi drivers drive carelessly } & 39 & 42 & 40 & 21 & 6 \\
\hline & 26.4 & 28.4 & 27.0 & 14.2 & 4.1 \\
\hline \multirow[t]{2}{*}{ 8. Some yellow taxis are dirty or poorly maintained } & 48 & 42 & 36 & 14 & 8 \\
\hline & 32.4 & 28.4 & 24.3 & 9.5 & 5.4 \\
\hline \multirow[t]{2}{*}{ 9. It is difficult to find yellow taxis at night } & 59 & 42 & 27 & 15 & 5 \\
\hline & 39.9 & 28.4 & 18.2 & 10.1 & 3.4 \\
\hline $\begin{array}{l}\text { 10. Some yellow taxi drivers obstruct or do not } \\
\text { display their information card }\end{array}$ & 48 & 46 & 29 & 15 & 10 \\
\hline
\end{tabular}

Table 2. Chi-square testing for experiences with yellow taxis before Uber

\begin{tabular}{|c|c|c|c|c|c|}
\hline Statement & $\begin{array}{l}\text { Chi- } \\
\text { square }\end{array}$ & $\mathrm{Df}$ & Sig. & Median & Scale \\
\hline 1. I have to walk some distance to catch a yellow taxi & 33.597 & 4 & 0.000 & 4.00 & Agree \\
\hline $\begin{array}{l}\text { 2. Yellow taxi drivers are sometimes picky; I prefer young } \\
\text { drivers or individuals without family luggage }\end{array}$ & 59.178 & 4 & 0.000 & 4.00 & Agree \\
\hline $\begin{array}{l}\text { 3. Yellow taxi drivers sometimes refuse to go to some } \\
\text { destinations or routes }\end{array}$ & 132.667 & 4 & 0.000 & 5.00 & $\begin{array}{l}\text { Strongly } \\
\text { agree }\end{array}$ \\
\hline 4. Some yellow taxi drivers are rude & 47.085 & 4 & 0.000 & 4.00 & Agree \\
\hline $\begin{array}{l}\text { 5. Some yellow taxi drivers ask for higher fare/payment or } \\
\text { do not use the meter }\end{array}$ & 33.442 & 4 & 0.000 & 4.00 & Agree \\
\hline $\begin{array}{l}\text { 6. Some yellow taxi drivers get other passengers to share } \\
\text { with you to maximise their income }\end{array}$ & 14.062 & 4 & 0.000 & 3.00 & Neutral \\
\hline 7. Some yellow taxi drivers drive carelessly & 25.147 & 4 & 0.000 & 4.00 & Agree \\
\hline 8. Some yellow taxis are dirty or poorly maintained & 35.147 & 4 & 0.000 & 4.00 & Agree \\
\hline 9. It is difficult to find yellow taxis at night & 52.822 & 4 & 0.000 & 4.00 & Agree \\
\hline $\begin{array}{l}\text { 10. Some yellow taxi drivers obstruct or do not display their } \\
\text { information card }\end{array}$ & 36.620 & 4 & 0.000 & 4.00 & Agree \\
\hline
\end{tabular}

The key findings from Table 2 can be interpreted as follows:

1. The Chi-square value for the statement I have to walk some distance to catch a yellow taxi was (33.597) with P-value (0.000), which is lower than the level of significance (5\%).

2. The Chi-square value for the statement yellow taxi drivers are sometimes picky; I prefer young drivers or individuals without family luggage was (59.178) with P-value (0.000), which is lower than the level of significance $(5 \%)$.

3. The Chi-square value for the statement yellow taxi drivers sometimes refuse to go to some destinations or routes was (132.667) with P-value (0.000), which is lower than the level of significance (5\%). 
4. The Chi-square value for the statement some yellow taxi drivers are rude was (47.085) with P-value (0.000), which is lower than the level of significance $(5 \%)$.

5. The Chi-square value for the statement some yellow taxi drivers ask for higher fare/payment or do not use the meter was (33.442) with P-value (0.000), which is lower than the level of significance $(5 \%)$.

6. The Chi-square value for the statement some yellow taxi drivers get other passengers to share with you to maximise their income was (14.062) with P-value (0.000), which is lower than the level of significance $(5 \%)$.

7. The Chi-square value for the statement some yellow taxi drivers drive carelessly was (25.147) with Pvalue $(0.000)$, which is lower than the level of significance $(5 \%)$.

8. The Chi-square value for the statement some yellow taxis are dirty or poorly maintained was (35.147) with P-value (0.000), which is lower than the level of significance (5\%).

9. The Chi-square value for the statement it is difficult to find yellow taxis at night was (52.822) with Pvalue $(0.000)$, which is lower than the level of significance $(5 \%)$.

10. The Chi-square value for the statement some yellow taxi drivers obstruct or do not display their information card was (36.620) with P-value (0.000), which is lower than the level of significance (5\%).

There is consensus on the main issues regarding yellow taxis in Jordan. Nine out of ten of the listed points were agreed upon; there was a neutral response to some yellow taxi drivers gets other passengers to share with you to maximize their income. Hence, it can be concluded that participants reported a high level of dissatisfaction with the yellow taxi services in Amman, corroborating findings our earlier study as well. Therefore, that might be seen as one of the driving factors for the quick deployment of Uber taxi services in Jordan as a good option for Jordanians to have quality taxi services.

\subsection{Disadvantages of Uber Taxi Services}

Table 3 displays respondents' answers about the disadvantages of Uber taxi services. Table 4 shows the Chi-square test results for respondents' answers about the disadvantages of Uber taxi services.

Table 3. Disadvantages of Uber taxi services

\begin{tabular}{|c|c|c|c|c|c|}
\hline Statement & $\begin{array}{l}\text { Strongly } \\
\text { agree }\end{array}$ & Agree & Neutral & Disagree & $\begin{array}{l}\text { Strongly } \\
\text { disagree }\end{array}$ \\
\hline \multirow{2}{*}{$\begin{array}{l}\text { 1. Subject to satellite navigation/GPS error, } \\
\text { mainly in urban environments }\end{array}$} & 10 & 19 & 50 & 45 & 24 \\
\hline & 6.8 & 12.8 & 33.8 & 30.4 & 16.2 \\
\hline \multirow[t]{2}{*}{ 2. Relatively more expensive than yellow taxis } & 41 & 32 & 40 & 24 & 11 \\
\hline & 27.7 & 21.6 & 27.0 & 16.2 & 7.4 \\
\hline \multirow[t]{2}{*}{ 3. Being unregulated is an issue } & 30 & 29 & 40 & 25 & 24 \\
\hline & 20.3 & 19.6 & 27.0 & 16.9 & 16.2 \\
\hline \multirow{2}{*}{$\begin{array}{l}\text { 4. Cultural or social norms makes it a challenge for } \\
\text { both drivers and passengers }\end{array}$} & 19 & 25 & 43 & 22 & 39 \\
\hline & 12.8 & 16.9 & 29.1 & 14.9 & 26.4 \\
\hline \multirow[t]{2}{*}{ 5. Card payment option can be seen as a challenge } & 16 & 24 & 39 & 24 & 45 \\
\hline & 10.8 & 16.2 & 26.4 & 16.2 & 30.4 \\
\hline \multirow[t]{2}{*}{ 6. Drivers may lack experience } & 22 & 16 & 48 & 28 & 34 \\
\hline & 14.9 & 10.8 & 32.4 & 18.9 & 23.0 \\
\hline \multirow{2}{*}{$\begin{array}{l}\text { 7. Sharing information might be seen as an issue } \\
\text { by some people }\end{array}$} & 21 & 29 & 49 & 23 & 26 \\
\hline & 14.2 & 19.6 & 33.1 & 15.5 & 17.6 \\
\hline \multirow{2}{*}{$\begin{array}{l}\text { 8. Car and passenger insurance might concern } \\
\text { some passengers }\end{array}$} & 23 & 25 & 53 & 19 & 28 \\
\hline & 15.5 & 16.9 & 35.8 & 12.8 & 18.9 \\
\hline \multirow{2}{*}{$\begin{array}{l}\text { 9. Parking or waiting areas in public places might } \\
\text { be an issue }\end{array}$} & 25 & 25 & 50 & 25 & 23 \\
\hline & 16.9 & 16.9 & 33.8 & 16.9 & 15.5 \\
\hline \multirow{2}{*}{$\begin{array}{l}\text { 10. Uber taxi drivers might be challenged by or } \\
\text { clash with yellow taxi drivers/owners }\end{array}$} & 39 & 32 & 46 & 17 & 14 \\
\hline & 26.4 & 21.6 & 31.1 & 11.5 & 9.5 \\
\hline
\end{tabular}


Table 4. Chi-square testing for disadvantages of Uber taxi services

\begin{tabular}{|c|c|c|c|c|c|}
\hline Statement & $\begin{array}{l}\text { Chi- } \\
\text { square }\end{array}$ & Df & Sig. & Median & Scale \\
\hline $\begin{array}{l}\text { 1. Subject to satellite navigation/GPS error, mainly in urban } \\
\text { environments }\end{array}$ & 38.171 & 4 & 0.000 & 3.00 & Neutral \\
\hline 2. Relatively more expensive than yellow taxis & 15.147 & 4 & 0.000 & 3.00 & Neutral \\
\hline 3. Being unregulated is an issue & 3.984 & 4 & 0.000 & 3.00 & Neutral \\
\hline $\begin{array}{l}\text { 4. Cultural or social norms makes it a challenge for both drivers } \\
\text { and passengers }\end{array}$ & 16.233 & 4 & 0.000 & 3.00 & Neutral \\
\hline 5. Card payment option can be seen as a challenge & 22.202 & 4 & 0.000 & 2.00 & Neutral \\
\hline 6. Drivers may lack experience & 23.209 & 4 & 0.000 & 3.00 & Neutral \\
\hline 7. Sharing information might be seen as an issue by some people & 12.589 & 4 & 0.000 & 3.00 & Neutral \\
\hline 8. Car and passenger insurance might concern some passengers & 21.349 & 4 & 0.000 & 3.00 & Neutral \\
\hline 9. Parking or waiting areas in public places might be an issue & 12.977 & 4 & 0.000 & 3.00 & Neutral \\
\hline $\begin{array}{l}\text { 10. Uber taxi drivers might be challenged by or clash with yellow } \\
\text { taxi drivers/owners }\end{array}$ & 22.124 & 4 & 0.000 & 3.00 & Neutral \\
\hline
\end{tabular}

The results of Table 4 can be interpreted as follows:

1. The Chi-square value for the statement subject to satellite navigation/GPS error, mainly in urban environments was (38.171) with P-value (0.000), which is lower than the level of significance (5\%).

2. The Chi-square value for the statement relatively more expensive than yellow taxis was (15.147) with Pvalue (0.000), which is lower than the level of significance (5\%).

3. The Chi-square value for the statement being unregulated is an issue was (3.984) with P-value (0.000), which is lower than the level of significance (5\%).

4. The Chi-square value for the statement cultural or social norms makes it a challenge for both drivers and passengers was (16.233) with P-value (0.000), which is lower than the level of significance (5\%).

5. The Chi-square value for the statement card payment option can be seen as a challenge was (22.202) with P-value (0.000), which is lower than the level of significance (5\%).

6. The Chi-square value for the statement drivers may lack experience was (23.209) with P-value (0.000), which is lower than the level of significance (5\%).

7. The Chi-square value for the statement sharing information might be seen as an issue by some people was (12.589) with P-value (0.000), which is lower than the level of significance (5\%).

8. The Chi-square value for the statement car and passenger insurance might concern some passengers was (21.349) with P-value (0.000), which is lower than the level of significance (5\%).

9. The Chi-square value for the statement parking or waiting areas in public places might be an issue was (12.977) with P-value (0.000), which is lower than the level of significance (5\%).

10. The Chi-square value for the statement Uber taxi drivers might be challenged by or clash with yellow taxi drivers/owners was (22.124) with P-value (0.000), which is lower than the level of significance (5\%).

The participants reflected neutral opinions on the ten listed disadvantages of Uber taxi services, in contrast to previous literature, specifically being unregulated is an issue, more expensive than yellow taxi and insurance might be a concern for some passengers). The only possible justification for this is that the high level of dissatisfaction with yellow taxi services and the low level of competition cause Jordanians to see the disadvantages of Uber as irrelevant. Furthermore, Jordanian might accept the expense of Uber taxi services, as some yellow taxi drivers might overcharge. In addition, Jordanians might use unregulated Uber taxi services as it is often difficult to find a yellow taxi. Finally, Jordanians might see modern Uber vehicles as a safer option than yellow taxis.

\subsection{Advantages of Uber Taxi Services}

Table 5displays respondents' answers about the advantages of Uber taxi services. 
Table 5. Advantages of Uber taxi services

\begin{tabular}{|c|c|c|c|c|c|}
\hline Statement & $\begin{array}{l}\text { Strongly } \\
\text { agree }\end{array}$ & Agree & Neutral & Disagree & $\begin{array}{l}\text { Strongly } \\
\text { disagree }\end{array}$ \\
\hline \multirow[t]{2}{*}{ 1. It offers a good way to plan my journey } & 68 & 32 & 29 & 9 & 10 \\
\hline & 45.9 & 21.6 & 19.6 & 6.1 & 6.8 \\
\hline \multirow[t]{2}{*}{ 2. It provides anytime, anywhere services } & 81 & 29 & 21 & 14 & 3 \\
\hline & 54.7 & 19.6 & 14.2 & 9.5 & 2.0 \\
\hline \multirow[t]{2}{*}{ 3. New and well-maintained cars } & 76 & 36 & 23 & 10 & 3 \\
\hline & 51.4 & 24.3 & 15.5 & 6.8 & 2.0 \\
\hline \multirow[t]{2}{*}{ 4. Likely to have kind and polite driver } & 53 & 44 & 34 & 12 & 5 \\
\hline & 35.8 & 29.7 & 23.0 & 8.1 & 3.4 \\
\hline \multirow{4}{*}{$\begin{array}{l}\text { 5. Options to choose from available listed drivers } \\
\text { and cars } \\
\text { 6. Follows global standards }\end{array}$} & 45 & 35 & 43 & 19 & 6 \\
\hline & 30.4 & 23.6 & 29.1 & 12.8 & 4.1 \\
\hline & 50 & 32 & 44 & 19 & 3 \\
\hline & 33.8 & 21.6 & 29.7 & 12.8 & 2.0 \\
\hline \multirow[t]{2}{*}{ 7. It enables ranking for both passengers and drivers } & 59 & 39 & 33 & 14 & 3 \\
\hline & 39.9 & 26.4 & 22.3 & 9.5 & 2.0 \\
\hline \multirow{6}{*}{$\begin{array}{l}\text { 8. It helps people to have the option not to use } \\
\text { private cars all the time and travel with taxis } \\
\text { 9. It offers people another transport option when } \\
\text { they are unable to drive (e.g. for medical reasons) } \\
\text { 10. It helps in solving unemployment issues and } \\
\text { helps offer supplementary income to some }\end{array}$} & 56 & 36 & 34 & 16 & 6 \\
\hline & 37.8 & 24.3 & 23.0 & 10.8 & 4.1 \\
\hline & 62 & 39 & 28 & 14 & 5 \\
\hline & 41.9 & 26.4 & 18.9 & 9.5 & 3.4 \\
\hline & 76 & 33 & 23 & 12 & 4 \\
\hline & 51.4 & 22.3 & 15.5 & 8.1 & 2.7 \\
\hline
\end{tabular}

Table 6 shows the Chi-square test results for respondents' answers about the advantages of Uber taxi services.

Table 6. Chi-square testing for advantages of Uber taxi services

\begin{tabular}{|c|c|c|c|c|c|}
\hline Statement & $\begin{array}{l}\text { Chi- } \\
\text { square }\end{array}$ & Df & Sig. & Median & Scale \\
\hline 1. It offers a good way to plan my journey & 58.403 & 4 & 0.000 & 4.00 & Agree \\
\hline 2. It provides anytime, anywhere services & 113.674 & 4 & 0.000 & 5.00 & $\begin{array}{l}\text { Strongly } \\
\text { agree }\end{array}$ \\
\hline 3. New and well-maintained cars & 92.589 & 4 & 0.000 & 5.00 & $\begin{array}{l}\text { Strongly } \\
\text { agree }\end{array}$ \\
\hline 4. Likely to have kind and polite driver & 44.062 & 4 & 0.000 & 4.00 & Agree \\
\hline 5. Options to choose from available listed drivers and cars & 33.054 & 4 & 0.000 & 4.00 & Agree \\
\hline 6. Follows global standards & 40.419 & 4 & 0.000 & 4.00 & Agree \\
\hline 7. It enables ranking for both passengers and drivers & 48.326 & 4 & 0.000 & 4.00 & Agree \\
\hline $\begin{array}{l}\text { 8. It helps people to have the option not to use private cars } \\
\text { all the time and travel with taxis }\end{array}$ & 41.116 & 4 & 0.000 & 4.00 & Agree \\
\hline $\begin{array}{l}\text { 9. It offers people another transport option when they are } \\
\text { unable to drive (e.g. for medical reasons) }\end{array}$ & 51.736 & 4 & 0.000 & 4.00 & Agree \\
\hline $\begin{array}{l}\text { 10. It helps in solving unemployment issues and helps offer } \\
\text { supplementary income to some }\end{array}$ & 83.442 & 4 & 0.000 & 5.00 & $\begin{array}{l}\text { Strongly } \\
\text { agree }\end{array}$ \\
\hline
\end{tabular}

The results of Table (6) can be interpreted as follows:

1. The Chi-square value for the statement it offers a good way to plan my journey was (58.403) with P-value (0.000), which is lower than the level of significance (5\%).

2. The Chi-square value for the statement it provides anytime, anywhere services was (113.674) with Pvalue $(0.000)$, which is lower than the level of significance (5\%).

3. The Chi-square value for the statement new and well-maintained cars was (92.589) with P-value (0.000), which is lower than the level of significance (5\%). 
4. The Chi-square value for the statement likely to have kind and polite driver was (44.062) with P-value (0.000), which is lower than the level of significance $(5 \%)$.

5. The Chi-square value for the statement options to choose from available listed drivers and cars was (33.054) with P-value (0.000), which is lower than the level of significance (5\%).

6. The Chi-square value for the statement follows global standards was (40.419) with P-value (0.000), which is lower than the level of significance $(5 \%)$.

7. The Chi-square value for the statement it enables ranking for both passengers and drivers was (48.326) with P-value (0.000), which is lower than the level of significance (5\%).

8. The Chi-square value for the statement it helps people to have the option not to use private cars all the time and travel with taxis was (41.116) with P-value (0.000), which is lower than the level of significance $(5 \%)$.

9. The Chi-square value for the statement it offers people another transport option when they are unable to drive (e.g. for medical reasons) was (51.736) with P-value (0.000), which is lower than the level of significance (5\%).

10. The Chi-square value for the statement it helps in solving unemployment issues and helps offer supplementary income to some was (83.442) with P-value (0.000), which is lower than the level of significance $(5 \%)$.

As expected, participants agreed on seven of the listed advantages and strongly agreed on three of them: it provides anytime, anywhere services, new and well-maintained cars and it helps in solving unemployment issues and helps offer supplementary income to some. The first two are natural reflections of the situation presented in the preceding two sections, while the third point is linked with the economic difficulties of Jordan which compel people to seek second job opportunities to cope with the high cost of living and/or to pay their car instalments.

\subsection{Future of Uber in Jordan}

Table 7displays respondents' answers about the future of Uber taxi services.

Table 7. The future of Uber taxi services

\begin{tabular}{|c|c|c|c|c|c|}
\hline Statement & $\begin{array}{l}\text { Strongly } \\
\text { agree }\end{array}$ & Agree & Neutral & Disagree & $\begin{array}{l}\text { Strongly } \\
\text { disagree }\end{array}$ \\
\hline \multirow{4}{*}{$\begin{array}{l}\text { 1. It will be regulated by government in the near } \\
\text { future } \\
2 \text {. Uber will bring prices down and attract more } \\
\text { passengers }\end{array}$} & 63 & 23 & 37 & 17 & 8 \\
\hline & 42.6 & 15.5 & 25.0 & 11.5 & 5.4 \\
\hline & 56 & 35 & 35 & 16 & 6 \\
\hline & 37.8 & 23.6 & 23.6 & 10.8 & 4.1 \\
\hline \multirow{2}{*}{$\begin{array}{l}\text { 3. Yellow taxi drivers/owners will start using } \\
\text { similar applications, which will make it harder for } \\
\text { competitors }\end{array}$} & 42 & 31 & 41 & 24 & 10 \\
\hline & 28.4 & 20.9 & 27.7 & 16.2 & 6.8 \\
\hline \multirow{4}{*}{$\begin{array}{l}\text { 4. Uber taxi services should be allowed but the } \\
\text { number of Uber cars should be controlled } \\
\text { 5. Uber or similar technologies are the future }\end{array}$} & 43 & 35 & 40 & 18 & 12 \\
\hline & 29.1 & 23.6 & 27.0 & 12.2 & 8.1 \\
\hline & 68 & 35 & 25 & 14 & 6 \\
\hline & 45.9 & 23.6 & 16.9 & 9.5 & 4.1 \\
\hline
\end{tabular}

Table 8 shows the Chi-square test results for respondents' answers about the future of Uber taxi services. 
Table 8. Chi-square testing for future of Uber taxi services

\begin{tabular}{|c|c|c|c|c|c|}
\hline Statement & $\begin{array}{l}\text { Chi- } \\
\text { square }\end{array}$ & Df & Sig. & Median & Scale \\
\hline 1. It will be regulated by government in the near future & 56.775 & 4 & 0.000 & 4.00 & Agree \\
\hline 2. Uber will bring prices down and attract more passengers & 46.698 & 4 & 0.000 & 4.00 & Agree \\
\hline $\begin{array}{l}\text { 3. Yellow taxi drivers/owners will start using similar } \\
\text { applications, which will make it harder for competitors }\end{array}$ & 16.853 & 4 & 0.000 & 3.00 & Neutral \\
\hline $\begin{array}{l}\text { 4. Uber taxi services should be allowed but the number of Uber } \\
\text { cars should be controlled }\end{array}$ & 21.194 & 4 & 0.000 & 4.00 & Agree \\
\hline 5. Uber or similar technologies are the future & 60.961 & 4 & 0.000 & 4.00 & Agree \\
\hline
\end{tabular}

The results of Table 8 can be interpreted as follows:

1. The Chi-square value for the statement it will be regulated by government in the near future was (56.775) with P-value (0.000), which is lower than the level of significance (5\%).

2. The Chi-square value for the statement Uber will bring prices down and attract more passengers was (46.698) with P-value (0.000), which is lower than the level of significance (5\%).

3. The Chi-square value for the statement yellow taxi drivers/owners will start using similar applications, which will make it harder for competitors was (16.853) with P-value (0.000), which is lower than the level of significance (5\%).

4. The Chi-square value for the statement Uber taxi services should be allowed but the number of Uber cars should be controlled was (21.194) with P-value (0.000), which is lower than the level of significance $(5 \%)$.

5. The Chi-square value for the statement Uber or similar technologies are the futurewas (60.961) with Pvalue (0.000), which is lower than the level of significance (5\%).

It seems that participants are optimistic about the future of Uber in Jordan, seeing Uber or similar technologies as the future, and they expected it to be regulated by government and to reduce prices. However, they are in the favour of controlling the number of Uber cars. On the other hand, participants seem to be cautious about the future of yellow taxi services by expressing a neutral position about yellow taxi drivers/owners starting to use similar applications.

Deeper analysis revealed that there are no substantive differences in responses between male and female participants, type and level of Uber taxi usage; consequently, there is a high level of agreement among participants.

\subsection{Statistical Analysis}

In order to check if results might vary according to participants, three more statistical tests were conducted: T-test between males and females, T-test between usage categorisation (frequent or occasional) and ANOVA test between four groups of users ( 1 to 10,11 to 20,21 to 30 and $>30$ ).

\subsubsection{T-Test for Gender}

Table 9. T-test for gender

\begin{tabular}{llllllll}
\hline Section & Sex & N & Mean & SD & T & Df & Sig. \\
\hline 1 & Female & 62 & 3.73 & $\mathbf{0 . 8 9 0}$ & $\mathbf{- 0 . 9 2 0}$ & 146 & $\mathbf{0 . 3 5}$ \\
$(1-10)$ & Male & 86 & 3.86 & $\mathbf{0 . 8 7 0}$ & & & \\
2 & Female & 62 & 2.97 & $\mathbf{0 . 7 6 8}$ & $\mathbf{- 0 . 2 4 7}$ & 146 & $\mathbf{0 . 8 0}$ \\
$(11-20)$ & Male & 86 & 3.00 & $\mathbf{0 . 7 9 7}$ & & & \\
3 & Female & 62 & 3.89 & $\mathbf{0 . 9 7 7}$ & $\mathbf{- 0 . 7 3 5}$ & 146 & $\mathbf{0 . 4 6}$ \\
$(21-30)$ & Male & 86 & 4.00 & $\mathbf{0 . 8 8 1}$ & & & \\
4 & Female & 62 & 3.71 & 1.014 & $\mathbf{0 . 0 7 2}$ & 146 & $\mathbf{0 . 9 4}$ \\
$(>30)$ & Male & 86 & 3.70 & $\mathbf{0 . 9 9 5}$ & & & \\
\hline
\end{tabular}

Analysing T-test result for gender (Table 9), it can be observed that section 1 (1 to 10) was (-0.920) with a significance value of (0.35), which is more than the level of significance (5\%). The section $2(11-20)$ was $(-0.247)$ 
with a significance value of (0.80), which is more than the level of significance (5\%). The section 3 (21-30) was ($0.735)$ with a significance value of $(0.46)$, which is more than the level of significance $(5 \%)$. The section $4(>30)$ was $(-0.072)$ with a significance value of $(0.94)$, which is more than the level of significance $(5 \%)$.

\subsubsection{T-Test for Taxi User Category}

The T-test result for taxi user category (Table 10$)$, section 1 (1 to 10$)$ was $(0.442)$ with a significance value of (0.65), which is more than the level of significance (5\%).

Table 10. T-test for taxi user category

\begin{tabular}{llllllll}
\hline Section & Service & N & Mean & SD & T & Df & Sig. \\
\hline 1 & Primary & 117 & 3.82 & 0.857 & 0.442 & 146 & 0.65 \\
$(1-10)$ & Secondary & 31 & 3.74 & 0.965 & & & \\
2 & Primary & 117 & 3.01 & 0.782 & 0.665 & 146 & 0.50 \\
$(11-20)$ & Secondary & 31 & 2.90 & 0.790 & & & \\
3 & Primary & 117 & 3.97 & 0.895 & 0.554 & 146 & 0.58 \\
$(21-30)$ & Secondary & 31 & 3.87 & 1.024 & & & \\
4 & Primary & 117 & 3.74 & 0.984 & 0.966 & 146 & 0.33 \\
\cline { 2 - 5 }$(>30)$ & Secondary & 31 & 3.55 & 1.060 & & & \\
\hline
\end{tabular}

The section 2 (11 to 20 ) was $(0.665)$ with a significance value of $(0.50)$, which is more than the level of significance $(5 \%)$. The T-test result for taxi user category, section 3 (21 to 30) was (0.554) with a significance value of (0.58), which is more than the level of significance $(5 \%)$. The section $4(>30)$ was $(0.966)$ with a significance value of (0.33), which is more than the level of significance (5\%).

\subsubsection{ANOVA Test between Four User Groups}

ANOVA was performed for the four sections of user groups ( 1 to 10,11 to 20,21 to 30 and $>30$ ). The value of (f) test calculated to signify the differences between the numbers of individuals of the study was (0.195) with a significance value of $(0.659)$, which is more than the level of significance $(5 \%)$.

Table 11. ANOVA between four user groups

\begin{tabular}{cccccc}
\hline $\begin{array}{c}\text { Source of } \\
\text { Variance }\end{array}$ & $\begin{array}{c}\text { Sum of } \\
\text { Squares }\end{array}$ & Df & $\begin{array}{c}\text { Mean } \\
\text { square }\end{array}$ & F & Sig. \\
\hline Between groups & 0.151 & 1 & 0.151 & 0.195 & 0.659 \\
\hline $\begin{array}{c}\text { Within groups } \\
\text { Total }\end{array}$ & 113.166 & 146 & 0.775 & & \\
\hline
\end{tabular}

Table 12. Descriptive statistics between four user groups

\begin{tabular}{ccccc}
\hline Valid & N & Range & Mean & SD \\
\hline $\mathbf{1}$ to $\mathbf{1 0}$ & 118 & 4 & 3.80 & 0.878 \\
$\mathbf{1 1}$ to 20 & 9 & 4 & 2.99 & 0.782 \\
$\mathbf{2 1}$ to 30 & 9 & 4 & 3.95 & 0.921 \\
$>\mathbf{3 0}$ & 12 & 4 & 3.70 & 1.000 \\
\hline
\end{tabular}

\section{Limitations and Scope of Future Work}

Due to the lack of public research on Uber taxi services in Jordan, the literature review was limited to works available in the public domain and reviews of studies conducted in other countries which might not share the same circumstances as Jordan.

Due to the limited time frame to perform data collection, the number of questionnaire responses gathered was 148; while this is respectable, more responses would have conferred greater strength on the findings.

The study was targeted only to passengers; input from other stakeholders would help in obtaining a more comprehensive overview of Uber taxi services.

There are few future recommendations as follows: 
- Findings can be enhanced with a wider sample of participants from Amman and other cities in Jordan.

- Other studies might be conducted with the inclusion of other stakeholders (e.g. taxi drivers, business owners and regulators).

- Other studies might be conducted to tackle challenges (disadvantages) related to Uber taxi services in Jordan, mainly those connected with the cultural and social norms.

- Other studies might be conducted on the role of Uber taxi services in cutting unemployment.

- Other studies can be concocted on how yellow taxi services can be improved to regain passengers' trust and enhance their quality of service.

\section{Conclusion}

The main aim of the research was to evaluate Jordanians' experiences with yellow taxi services and assess their opinions toward the advantages and disadvantages of Uber taxi services in Jordan. In addition, it sought to obtain opinions on the expected future of Uber taxi services. Available studies indicate that Uber is still very new and in the preliminary adoption stage in most countries in which it operates, facing general barriers to new technology such as regulation, pricing and safety. Nevertheless, Uber taxi service is becoming more appealing to passengers worldwide. Therefore, the finding from literature justified the motivation of the study to address a manifest gap in existing knowledge, and to provide a preliminary overview of Uber in Jordan that can serve as a basis for future research projects.

Jordanians have a negative experience with yellow taxi services and a high level of dissatisfaction. Uber disadvantages but it has its own particular disadvantages related to cultural, political and economic circumstances. While the main disadvantage of Uber is its expense, other disadvantages emphasised by participants were mainly related to perceived deficiencies in Jordanian readiness rather than being intrinsic to Uber per se, such as the lack of regulation, cultural barriers, the online card option (i.e. the lack of conventional cash payments), drivers may lack experience, sharing information might be seen as an issue by some people, and satellite navigation/GPS errors may be common, particularly in urban environments.

On the other hand, they identified a number of advantages: it allows them to plan their journey easily, the appearance of new cars seems more attractive, they are willing to use Uber taxi as a global standard, the ability to choose the driver they like, the friendliness of drivers, seeing Uber as contributing to reducing unemployment by providing a second job option, the possibility to rate the service and the particular utility of Uber for people who are unable to drive. Finally, compared to other studies, it seems that Uber taxi service offers extra advantages in Jordan and also faces different challenges (disadvantages) pertaining to cultural and social norms. Jordanians are in favour of Uber taxi services or similar technology and they see it as the future, and they strongly believe it will be regulated by government in the near future and fair prices will make it more affordable.

\section{References}

Bhuiyan, J. (2018). Uber powered four billion rides in 2017. It wants to do more - and cheaper - in 2018. Retrieved May 21, 2018, from https://www.recode.net/2018/1/5/16854714/uber-four-billion-rides-coobarney-harford-2018-cut-costs-customer-service

Chen, M. K., \& Sheldon, M. (2016). Dynamic pricing in a labor market: Surge pricing and flexible work on the Uber platform. Proceedings of the 2016 Acm Conference on Economics and Computation, 1-19. https://doi.org/10.1145/2940716.2940798

Creswell, J. W. (2003). Research design: Qualitative, quantitative, and mixed methods approaches (Second). Thousand Oaks, California: Sage Publications, Inc. Retrieved from https://ucalgary.ca/paed/files/paed/2003_creswell_a-framework-for-design.pdf

Gerdes, J. C., \& Thornton, S. M. (2015). Implementable ethics for autonomous vehicles. In Autonomes Fahren (pp. 87-102). Berlin, Heidelberg: Springer Berlin Heidelberg. https://doi.org/10.1007/978-3-662-45854-9_5

Glöss, M., McGregor, M., \& Brown, B. (2016). Designing for labour: Uber and the on-demand mobile workforce. In Proceedings of the 2016 CHI Conference on Human Factors in Computing Systems - CHI '16 (pp. 1632 1643). New York, New York, USA: ACM Press. https://doi.org/10.1145/2858036.2858476

Haider, M., Donaldson, L., \& Nourinejad, M. (2015). To Uber or not to Uber. Retrieved from https://www.researchgate.net/publication/282737402_To_Uber_or_Not_to_Uber?channel=doi\&linkId=561 b0a7408aea8036722b9b4\&showFulltext=true

Hartmans, A. (2016). Uber has $80 \%$ of ride-hailing market in U.S. Business Insider. Retrieved from http://uk.businessinsider.com/uber-majority-ride-hailing-market-share-lyft-us-20168? utm_source=feedly\&utm_medium $=$ webfeeds\&r=US\&IR $=\mathrm{T}$ 
Imam, R. (2014). Measuring public transport satisfaction from User surveys. International Journal of Business and Management, 9(6), 106-114. https://doi.org/10.5539/ijbm.v9n6p106

Jacquet, A. (2018). A power struggle in the taxi industry: A challenge for Uber and Lyft regarding their service clauses. PM World Journal, VII. Retrieved from www.pmworldjournal.net

Jha, S. S., Cheng, S. F., Lowalekar, M., Wong Rishikeshan, N., Trong, R., Tran, K., ... Rahman, B. A. (2018). Upping the game of taxi driving in the age of Uber. In Thirtieth Annual Conference on Innovative Applications of Artificial Intelligence (IAAI-18). New Orleans, Louisiana. Retrieved from http://www.mysmu.edu/faculty/sfcheng/pub/2018/iaai18-dgs-final.pdf

Jiang, S., Chen, L., Mislove, A., \& Wilson, C. (2018). On ridesharing competition and accessibility: Evidence from Uber, Lyft, and Taxi. In International World Wide Web Conference Committee (IW3C2). Lyon, France. https://doi.org/10.1145/3178876.3186134

Kashyap, R. (2018). Taxi drivers and taxidars: A case study of Uber and Ola in Delhi. Journal of Developing Societies, 34(2), 169-194. https://doi.org/10.1177/0169796X18757144

Kim, K., Baek, C., \& Lee, J. D. (2018). Creative destruction of the sharing economy in action: The case of Uber. Transportation Research Part A: Policy and Practice, 110, 118-127. https://doi.org/10.1016/J.TRA.2018.01.014

Landau, S., \& Everitt, B. S. (2004). A handbook of statistical analyses using SPSS. Boca Raton : Chapman \& Hall/CRC Press LLC . Retrieved http://www.academia.dk/BiologiskAntropologi/Epidemiologi/PDF/SPSS_Statistical_Analyses_using_SPSS .pdf

Lee, Y., Park, J., \& Lee, B. (2018). Battle of sharing economy: The contingent effects of ride-sharing on Taxi industry. In Proceedings of the 51st Hawaii International Conference on System Sciences (pp. 656-665). https://doi.org/10.24251/HICSS.2018.083

Maqableh, M., \& Karajeh, H. (2014). Job scheduling for cloud computing using neural networks. Communications and Network, 6(3), 191-200.

Millspaugh, $\quad$ B. $\quad(2013$, July 31). US9157748B2. Retrieved from https://patents.google.com/patent/US9157748B2/en

Millspaugh, B. (2015, October 9). US9488494B2. Retrieved from https://patents.google.com/patent/US9488494B2/en

Millspaugh, B. (2016, October 6). US9934691B2. USA. Retrieved from https://patents.google.com/patent/US9934691B2/en

Peticca-Harris, A., Degama, N., \& Ravishankar, M. N. (2018). Postcapitalist precarious work and those in the "drivers" seat: Exploring the motivations and lived experiences of Uber drivers in Canada. Organization, 124. https://doi.org/10.1177/1350508418757332

Salnikov, V., Lambiotte, R., Noulas, A., \& Mascolo, C. (2015). Open street cab: Exploiting taxi mobility patterns in New York city to reduce commuter costs. Retrieved from http://arxiv.org/abs/1503.03021

Smith, N. C., \& McCormick, E. (2019). Uber and the ethics of sharing: Exploring the societal promises and responsibilities of the sharing economy. In Managing Sustainable Business (pp. 579-611). Dordrecht: Springer Netherlands. https://doi.org/10.1007/978-94-024-1144-7_27

Uber. (2018). Retrieved March 24, 2018, from https://www.uber.com/en-GB/

Valladão, A. G. A. (2016). Climbing the global digital ladder: Latin America's inescapable trial. Research Papers \& Policy Papers. Retrieved from https://ideas.repec.org/p/ocp/rpaper/pp-16-09.html

Wang, M., \& Mu, L. (2018). Spatial disparities of Uber accessibility: An exploratory analysis in Atlanta, USA. Computers, Environment and Urban 169-175. https://doi.org/10.1016/J.COMPENVURBSYS.2017.09.003

Wegner, K. (2017). How much does Uber type application cost? Retrieved June 16, 2018, from https://itcraftapps.com/blog/how-much-does-it-cost-to-create-an-uber-type-application/

Yang, Z., Franz, M. L., Zhu, S., Mahmoudi, J., Nasri, A., \& Zhang, L. (2018). Analysis of Washington, DC taxi demand using GPS and land-use data. Journal of Transport Geography, 66, 35-44. https://doi.org/10.1016/J.JTRANGEO.2017.10.021 
Zha, L., Yin, Y., \& Du, Y. (2017). Surge pricing and labor supply in the ride-sourcing market. Transportation Research Procedia, 23, 2-21. https://doi.org/10.1016/J.TRPRO.2017.05.002

Zha, L., Yin, Y., \& Yang, H. (2016). Economic analysis of ride-sourcing markets. Transportation Research Part C: Emerging Technologies, 71, 249-266. https://doi.org/10.1016/J.TRC.2016.07.010

Zhang, Y., Guo, H., Li, C., \& Liu, Y. (2016). Which one is more attractive to traveler, Taxi or Tailored taxi? An empirical study in China. In Procedia Engineering (Vol. 137, pp. 867-875). Elsevier. https://doi.org/10.1016/J.PROENG.2016.01.327

Zhao, H., Dimovitz, K., Staveland, B., \& Medsker, L. (2016). Responding to challenges in the design of moral autonomous vehicles. In The 2016 AAAI Fall Symposium Series: Cognitive Assistance in Government and Public Sector Applications, Technical Report FS-16-02 (pp. 169-173). Retrieved from https://www.aaai.org/ocs/index.php/FSS/FSS16/paper/viewFile/14108/13685

\section{Copyrights}

Copyright for this article is retained by the author(s), with first publication rights granted to the journal.

This is an open-access article distributed under the terms and conditions of the Creative Commons Attribution license (http://creativecommons.org/licenses/by/4.0/). 